.. Humar, Lesar, Thaler, Kržišnik, Kregar, Drnovšek: Quality of Copper Impregnated Wood...

Miha Humarl, Boštjan Lesar ${ }^{1}$, Nejc Thaler ${ }^{1}$, Davor Kržišnik ${ }^{1}$, Nace Kregar $^{2}$, Simon Drnov̌̌ek²

\title{
Quality of Copper Impregnated Wood in Slovenian Hardware Stores
}

\section{Kvaliteta drva impregniranoga bakrom u slovenskim trgovinama građevnog materijala}

\author{
Original scientific paper • Izvorni znanstveni rad \\ Received-prispjelo: 16. 5. 2017. \\ Accepted-prihvaćeno: 23. 5. 2018. \\ UDK: $630 * 841.5$ \\ doi:10.5552/drind.2018.1732
}

\begin{abstract}
Ten different samples from Slovenian hardware stores were analysed. Samples were treated with copper based wood preservatives that were designed and advertised to be used in heavy duty applications in ground (use classes 4) and above ground (use classes 3.2). Retention and fungicidal properties were determined in order to establish the quality of treatment quality. Retention was determined by XRF analysis, while a modified EN 113 procedure was applied for the assessment of fungicidal properties. Two brown rot fungal species, Gloeophyllum trabeum and Fibroporia vaillantii, were used for durability testing. The results of the analysis clearly showed that only three of the inspected wood products met penetration requirements, and none of them had sufficient retention, which is also reflected in insufficient durability against wood decay fungi.
\end{abstract}

Keywords: wood, impregnation, penetration, quality control, degradation

\begin{abstract}
SAŽETAK • Za potrebe ovog rada analizirano je deset različitih uzoraka iz slovenskih prodavaonica građevnog materijala. Uzorci su tretirani zaštitnim sredstvima na bazi bakra namijenjenim i preporučenim za zahtjevne uvjete primjene u tlu (uporabna klasa 4) i iznad tla (uporabna klasa 3.2). Određeni su retencija i fungicidna svojstva tih sredstava kako bi se utvrdila kakvoća zaštite drva. Retencija zaštitnog sredstva određena je uz pomoć XRF analize, dok je modificirani postupak EN 113 primijenjen za procjenu fungicidnih svojstava zaštitnih sredstava. Za testiranje trajnosti poslužile su dvije vrste gljivica smeđe truleži, Gloeophyllum trabeum i Fibroporia vaillantii. Rezultati analize jasno su pokazali da su samo na tri istraživana drvna proizvoda bili ispunjeni zahtjevi penetracije zaštitnog sredstva, a ni na jednome drvnom uzorku nije postignuta dovoljna retencija zaštitnog sredstva, što se očituje i nedostatnom trajnošću drva izloženoga djelovanju gljiva truležnica.
\end{abstract}

Ključne riječi: drvo, impregnacija, penetracija, kontrola kvalitete, degradacija

\section{INTRODUCTION \\ 1. UVOD}

The importance of wood in Europe is increasing and more and more wood is used in outdoor applications (Lacič et al., 2014). Unfortunately, there are not many durable wood species available in Europe (Despot, 1998; Brischke, 2013). Hence, wood has to be pro- tected in some way if used in outdoor applications. Since the majority of alternative wood preservatives have been banned (Regulation 528/2012), copper based preservatives are among the few alternatives that are suitable for protection of wood in outdoor applications (Humar et al., 2001; Connell, 2004). However, as small customers are not able (or willing) to perform

\footnotetext{
${ }^{1}$ Authors are professor, assistant professor, assistant professor and PhD student at University of Ljubljana, Biotechnical Faculty, Ljubljana, Slovenia. ${ }^{2}$ Authors are engineers employed in Bureau Veritas, Ljubljana, Slovenia.

Autori su profesor, docent, docent i doktorand Sveučilišta u Ljubljani, Biotehnički fakultet, Ljubljana, Slovenija. ${ }^{2}$ Autori su zaposlenici tvrtke Bureau Veritas, Ljubljana, Slovenija.
} 
Table 1 Materials purchased in seven hardware stores in spring 2015.

Tablica 1. Materijali kupljeni u sedam trgovina građevnog materijala u proljeće 2015.

\begin{tabular}{|c|c|c|c|c|c|c|}
\hline \multirow{2}{*}{$\begin{array}{l}\text { Abbre- } \\
\text { viation } \\
\text { Oznaka }\end{array}$} & \multirow{2}{*}{$\begin{array}{l}\text { Form } \\
\text { Oblik }\end{array}$} & \multirow{2}{*}{$\begin{array}{l}\text { Wood species } \\
\text { Vrsta drva }\end{array}$} & \multirow{2}{*}{$\begin{array}{c}\text { Declared dimension } \\
\text { Deklarirane dimenzije } \\
\mathrm{mm}\end{array}$} & \multirow{2}{*}{$\begin{array}{c}\text { Actual dimension } \\
\text { Stvarne dimenzije } \\
\mathrm{mm}\end{array}$} & \multicolumn{2}{|c|}{ Price / Cijena } \\
\hline & & & & & $€ /$ piece & $€ / \mathrm{m}^{3}$ \\
\hline A & Batten / letva & Scots pine/obični bor & $90 \times 90 \times 1000$ & $85 \times 85 \times 1000$ & 5.59 & 690 \\
\hline $\mathrm{B}$ & Post / stup & Scots pine / obični bor & $\Phi 80 \times \times 1250$ & $\Phi 76 \times 1250$ & 3.29 & 548 \\
\hline $\mathrm{C}$ & Post / stup & Scots pine / obični bor & $\Phi 60 \times \times 1500$ & $\Phi 55 \times 1470$ & 2.89 & 723 \\
\hline $\mathrm{D}$ & Post / stup & Norway spruce / visoka smreka & $\Phi 80 \times \times 1250$ & $\Phi 80 \times 1250$ & 4.99 & 792 \\
\hline $\mathrm{E}$ & Post / stup & Scots pine / obični bor & $40 \times \times 40 \times \times 1500$ & $40 \times 40 \times 1500$ & 1.99 & 829 \\
\hline $\mathrm{F}$ & Batten / letva & Scots pine / obični bor & $70 \times 70 \times 1000$ & $66 \times 66 \times 1000$ & 3.98 & 812 \\
\hline G & Batten / letva & Norway spruce / visoka smreka & $50 \times 70 \times 2000$ & $49 \times 68 \times 2000$ & 5.69 & 813 \\
\hline $\mathrm{H}$ & Batten / letva & Scots pine / obični bor & $70 \times 70 \times 1000$ & $69 \times 69 \times 1000$ & 4.15 & 847 \\
\hline I & Batten / letva & Norway spruce / visoka smreka & $35 \times 85 \times 945$ & $35 \times 85 \times 945$ & 2.44 & 871 \\
\hline $\mathrm{J}$ & Post / stup & Norway spruce / visoka smreka & $\Phi 80 \times 1300$ & $\Phi 80 \times 1300$ & 4.50 & 692 \\
\hline
\end{tabular}

protection at home, they usually use wood from hardware stores. Unfortunately, this wood is not subjected to quality control protocols, so the quality of the impregnated wood does not always meet standards.

Quality control of wood in Europe is based on several standards. The essential one is EN 351-1 (CEN, 2007). This standard prescribes the penetration classes and the treated zone. There are six penetration classes defined, ranging from NP1 (no requirements) to NP6 (full sapwood penetration and $6 \mathrm{~mm}$ penetration to exposed heartwood). End users usually require spruce wood to meet penetration class NP3 (penetration of 6 $\mathrm{mm}$ ), while penetration class NP5 (full sapwood penetration) is required for Scots pine wood. In contrast to penetration, end users and specifiers usually prescribe retention. The retention requirement is the uptake of the formulation/active ingredients, expressed in $\mathrm{kg}_{\text {per }} \mathrm{m}^{3}$ of wood in the treated zone. This information is usually based on extensive field testing based on standard EN 599-1 (CEN, 2009), which prescribes which tests need to be performed for a particular use class. The list provided by the Nordic Wood Preservation Council (2008, 2015 ) is the reference most frequently applied by end users to prepare requirements for orders of impregnated wood. If wood is not treated correctly, failures can appear (Humar and Thaler, 2017), which leads to a bad reputation of wood preservation in general.

This research was performed in order to elucidate the quality of impregnated wood from hardware stores. Ten samples of copper treated wood that was advertised as being suitable for use in heavy-duty applications were purchased and analysed for suitability in outdoor applications.

\section{MATERIAL AND METHODS 2. MATERIJAL I METODE 2.1 Material \\ 2.1. Materijal}

Ten different products were purchased in the period between March and April 2015 in seven hardware stores (Table 1 Materials purchased in seven hardware stores in spring 2015.). Each product consisted of three individual pieces-specimens. Specimens in the shop were selected at random. Wood was declared to be suit- able for above- and in-ground applications. In addition, the shape of the posts clearly showed the potential use, and the colour and the declaration also clearly indicated that the wood had been treated with copper based preservatives.

The purchased material was marked and conditioned in the laboratory prior to analysis. Impregnated wood was cut into specimens suitable for further analysis, as explained in the following subchapters.

\subsection{Methods}

\subsection{Metode}

The quality of treatment is determined by the penetration and retention of the active ingredients (CEN, 2007). In order to elucidate these parameters, the poles and battens were cut into $3 \mathrm{~cm}$ thick cylinders. The first cylinder was located $10 \mathrm{~cm}$ from the edge. Cylinders were numbered. Odd numbered cylinders were used for penetration and retention analysis, while even numbered cylinders were used for durability testing. There were five cylinders per post used for penetration and retention and five for durability tests.

Penetration was determined visually. The depth of copper penetration was estimated on transverse planes, with a $1 \%$ aqueous solution of potassium hexacyanoferrate being used as the colour reagent for copper. Even wood impregnated with a lower concentration of copper turned brown in the presence of this reagent (Humar and Lesar, 2009). In addition, samples were scanned. The penetration of other active ingredients was not determined. Average values were calculated based on eight individual measurements performed in every respective sample.

In order to determine retention and to confirm the penetration studies, the cylinders were cut into thin layers; 0-2 mm, 2-5 $\mathrm{mm}$ and 5-12 $\mathrm{mm}$ in depth, for elemental XRF analysis. Layers were cut from outer part to central part. The dimensions of the layers were determined based on a visual assessment of penetration. Each layer was milled in a SM 2000 Retch mill (Retch $\mathrm{GmbH}$; Haan, Germany) and five parallel tablets ( $r=$ $16 \mathrm{~mm} ; h=5 \mathrm{~mm}$ ) were pressed from the milled material with a Chemplex Sprectro pellet press (Chemplex Industries Inc., USA). The copper and chromium con- 


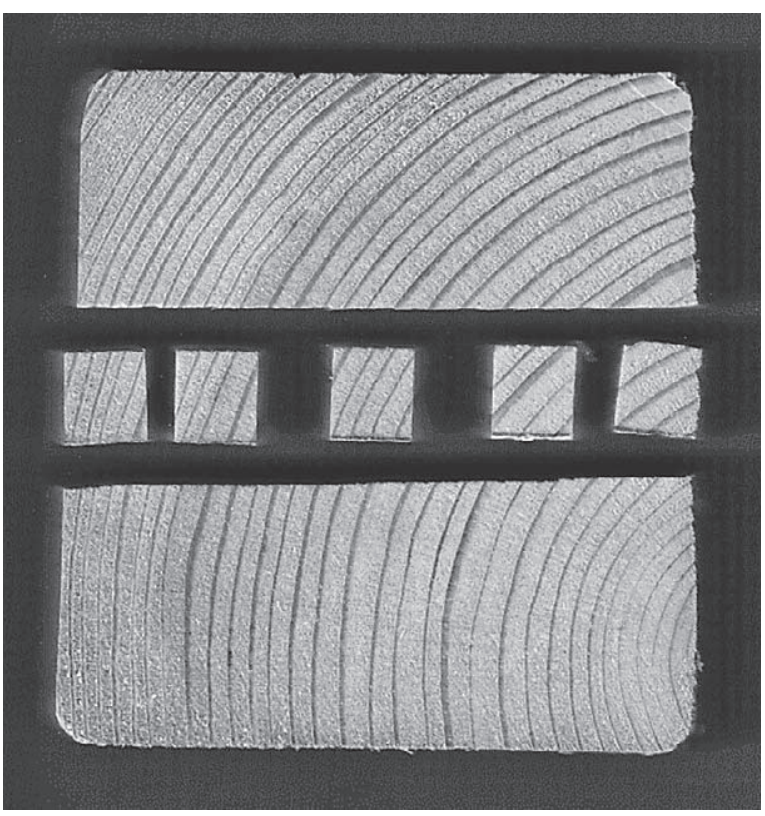

Figure 1 Position of the samples for durability testing. The outer specimens were used for assessment of fungicidal properties

Slika 1. Mjesto s kojega su uzeti uzorci za ispitivanje trajnosti; vanjski uzorci upotrijebljeni su za procjenu fungicidnih svojstava

tent in the tablets was determined with a Twin-X XRF spectrometer (XRF TwinX, Oxford instruments, UK). Measurements were performed with a PIN detector ( $U$ $=26 \mathrm{kV}, I=112 \mu \mathrm{A}, t=360 \mathrm{~s})$. In addition, copper retention was determined on matched specimens to those used for determination of fungicidal properties. From the copper content in treated wood, individual retentions were calculated based on the chemical composition of the most frequently used preservative solutions in the region. Retention is expressed as the average value of at least ten individual measurements.

A decay test was performed according to a modified EN 113 (CEN, 2006) standard protocol using specimens from all posts/battens as follows. Disposable Petri dishes $(\Phi=85 \mathrm{~mm}, h=15 \mathrm{~mm})$ containing $20 \mathrm{~mL}$ of $4 \%$ potato dextrose agar (PDA, Difco, NJ, USA) were inoculated with two brown rot fungal species: Gloeophyllum trabeum (Pers.) Murrill (ZIM L018) and Fibroporia vaillantii (DC.) Parmasto (ZIM L037). The fungal isolates originated from the fungal collection of the Biotechnical Faculty, University of Ljubljana and are available to research institutions on demand (Raspor et al., 1995). G. trabeum was chosen because it is one of the most important softwoods degrading fungi and is considered to be copper sensitive. In contrast, $F$. vaillantii was chosen as a copper tolerant fungal strain. A plastic mesh was used to avoid direct contact between the samples and the medium. The assembled test dishes were then incubated at $25^{\circ} \mathrm{C}$ and $80 \%$ relative humidity $(\mathrm{RH})$ for 12 weeks. Specimens of dimensions $10 \mathrm{~mm} \times 10 \mathrm{~mm} \times 20 \mathrm{~mm}$ were prepared and 5 replicates per fungal species were used for each group of treated woods (300 specimens in total). Specimens were made of the outer better-impregnated sapwood. Untreated Norway spruce and Scots pine speci- mens served as reference wood species to assess the validity of the test. After incubation, the fungal mycelium was removed and the samples were weighed to determine moisture content. After 24 hours of drying at $103^{\circ} \mathrm{C}$, mass loss was determined gravimetrically.

\section{RESULTS AND DISCUSION} 3. REZULTATI I RASPRAVA

XRF analysis confirmed the visual inspection that all of the treated wood used in this research had been treated with copper amine based wood preservatives. Selection of the preservative is in line with the intended use of the treated wood. Copper based wood preservatives are the most important option suitable for protection of wood in ground contact (Preston, 2000). However, as can be seen from the visual appearance of the cross-sections shown in Figure 2, the penetration of copper in most of the analysed treated wood does not meet the requirements. End users usually prescribe penetration class NP3 (penetration of at least $6 \mathrm{~mm}$ ) for spruce wood and NP5 (full sapwood penetration) for Scots pine wood for in-ground applications. As can be seen from Table 2, only three samples met the penetration criteria. The copper penetrated more than $6 \mathrm{~mm}$ deep with sample G, made of Norway spruce wood. The other two samples were made of Scots pine wood ( $\mathrm{H}$ and $\mathrm{J})$. Since we did not perform analysis of the wood before impregnation, we were unable to determine the reasons for insufficient penetration. There are probably two main reasons: too high moisture content of wood before impregnation and/or inappropriate impregnation procedure (Wilkinson, 1979). As sometimes even the sapwood of refractory Scots pine sapwood was not fully impregnated, we presume that the anatomical features and presence of heartwood are not the key reasons for insufficient penetration and retention. However, inappropriate treatment results in the premature failure of wood (Humar and Thaler, 2017) and could negatively influence the public perception of wood preservation.

In addition to penetration, retention also determines the quality of the impregnated wood, so retention was determined in the second step. Retention of copper based wood preservatives in use class 3 (aboveground, uncovered) should exceed $8 \mathrm{~kg} / \mathrm{m}^{3}$; however, for in-ground applications (use class 4), retention of 16 $\mathrm{kg} / \mathrm{m}^{3}$ is required. As can be seen in Table 2, only one batten exceeded the limit for use class 3 conditions (sample G), while none of the posts met the criteria for use class 4 conditions.

Analysis of the retention in different layers indicated that the retention of active ingredients in the outer layers (outer $2 \mathrm{~mm}$ ) exceeded the criteria for use class 3 conditions with $70 \%$ of the samples (Figure 3 Retention of copper based wood preservatives in different layers of analysed impregnated wood. Grey lines indicate prescribed retention levels for use classes 3 and 4.). However, retention and, consequently, the copper concentration in inner layers decreased significantly with the majority of samples. This indicates that the concentra- 
Table 2 Penetration and retention of copper based wood preservatives in the analysed impregnated wood (Values in bold indicate that the analysed treated wood meets the appropriate criteria. Standard deviation is given in parenthesis)

Tablica 2. Penetracija i retencija zaštitnog sredstva na bazi bakra u analiziranome impregniranom drvu (zadebljane vrijednosti pokazuju da analizirano zaštićeno drvo zadovoljava odgovarajuće kriterije; standardna odstupanja navedena su u zagradama)

\begin{tabular}{|c|c|c|c|c|}
\hline \multirow{2}{*}{$\begin{array}{l}\text { Abbre- } \\
\text { viation } \\
\text { Oznaka }\end{array}$} & \multirow{2}{*}{$\begin{array}{l}\text { Form } \\
\text { Oblik }\end{array}$} & \multirow{2}{*}{$\begin{array}{l}\text { Wood species } \\
\text { Vrsta drva }\end{array}$} & \multicolumn{2}{|c|}{ Criteria / Kriteriji } \\
\hline & & & $\begin{array}{l}\text { Penetration / Penetracija } \\
\mathrm{mm}\end{array}$ & $\begin{array}{c}\text { Retention / Retencija } \\
\mathrm{kg} / \mathrm{m}^{3}\end{array}$ \\
\hline $\mathrm{A}$ & Batten / letva & Scots pine / obični bor & 1.0 & $1.1(0.2)$ \\
\hline $\mathrm{B}$ & Post / stup & Scots pine / obični bor & 7.7 & $4.7(0.2)$ \\
\hline $\mathrm{C}$ & Post / stup & Scots pine / obični bor & 11.3 & $12.3(0.5)$ \\
\hline $\mathrm{D}$ & Post / stup & Norway spruce / visoka smreka & 4.3 & $1.8(0.1)$ \\
\hline $\mathrm{E}$ & Post / stup & Scots pine / obični bor & 5.0 & $5.6(0.1)$ \\
\hline $\mathrm{F}$ & Batten / letva & Scots pine / obični bor & 14.7 & $4.4(0.1)$ \\
\hline $\mathrm{G}$ & Batten / letva & Norway spruce / visoka smreka & 6.3 & $7.9(0.3)$ \\
\hline $\mathrm{H}$ & Batten / letva & Scots pine / obični bor & 21.7 & $2.9(0.1)$ \\
\hline I & Batten / letva & Norway spruce / visoka smreka & 3.7 & $7.2(0.1)$ \\
\hline $\mathrm{J}$ & Post / stup & Norway spruce / visoka smreka & 28.3 & $12.6(0.3)$ \\
\hline
\end{tabular}

tion of active ingredients in the preservative solution was sufficient but the procedure applied was inadequate or the moisture content of the wood was too high. However, with samples $\mathrm{A}, \mathrm{D}$ and $\mathrm{H}$, even the retention in the outer $2 \mathrm{~mm}$ did not exceed $5 \mathrm{~kg} / \mathrm{m}^{3}$, which is a catastrophic combination together with low retention.
In the final step, the efficiency of wood treatment against wood decay fungi was determined. Since all of the treated samples were made from conifers, only brown rot fungi were used. G. trabeum is a typical copper sensitive brown rot fungus. On the other hand, $F$. vaillantii has been proven to be a copper tolerant strain

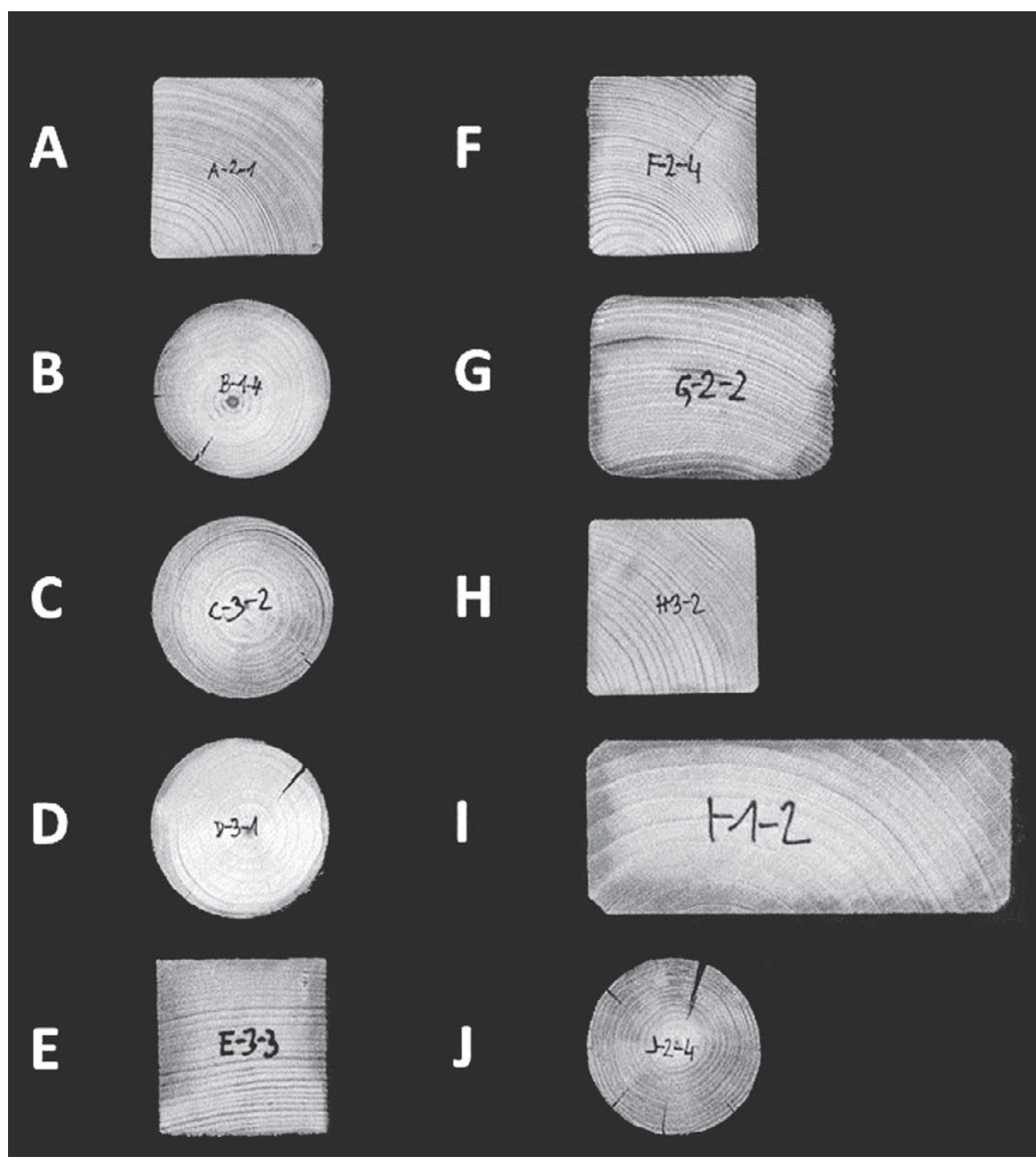

Figure 2 Cross-sections of analysed wood. The cross-sections are not in scale. Dimensions can be seen in Table 1 Slika 2. Presjeci analiziranog drva (poprečni presjeci nisu u mjerilu; dimenzije se mogu vidjeti u tablici 1.) 
.. Humar, Lesar, Thaler, Kržišnik, Kregar, Drnovšek: Quality of Copper Impregnated Wood...

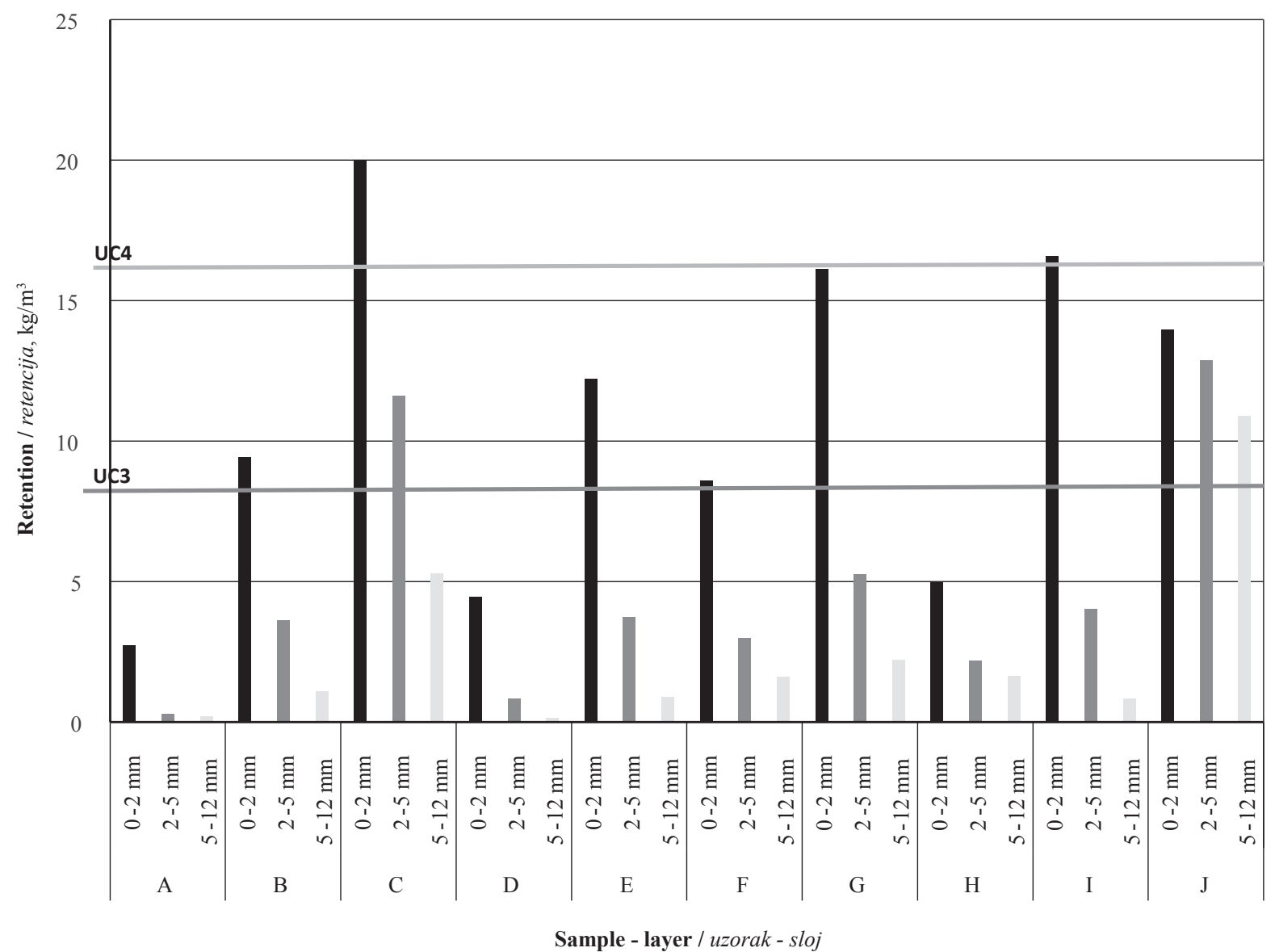

Figure 3 Retention of copper based wood preservatives in different layers of analysed impregnated wood. Grey lines indicate prescribed retention levels for use classes 3 and 4.

Slika 3. Retencija zaštitnog sredstva za drvo na bazi bakra u različitim slojevima analiziranoga impregniranog drva (sive linije pokazuje propisane razine retencije za klase primjene 3 i 4)

(Humar et al., 2006). Its copper tolerance can be clearly seen in Table 3 Mass losses of the copper treated wood species after exposure to brown rot fungi. Bold values indicate mass losses that did not exceed the $3 \%$ limit. Standard deviations are given in parenthesis.. This copper tolerant strain was able to degrade all of the wood samples used in the tests. It should be noted that these samples had not been leached or weathered, so high mass losses clearly indicate poor performance of the tested wood. Mass losses of the copper treated samples ranged between $10.8 \%$ (sample E) and $20.2 \%$ (samples $\mathrm{C}$ and G). It should be born in mind that poor performance of copper treated wood is not only the result of high copper tolerance but also of poor penetration. Although we tried to prepare the samples from the impregnated part of the tested wood, this was not always pos-

Table 3 Mass losses of the copper treated wood species after exposure to brown rot fungi. Bold values indicate mass losses that did not exceed the 3\% limit. Standard deviations are given in parenthesis.

Tablica 3. Gubitci mase uzoraka drva premazanoga zaštitnim sredstvom na bazi bakra nakon izlaganja gljivicama smeđe truleži (zadebljane vrijednosti pokazuju masene gubitke koji ne prelaze granicu od $3 \%$; standardna su odstupanja navedena u zagradama)

\begin{tabular}{|c|l|l|c|c|}
\hline $\begin{array}{c}\text { Abbreviation } \\
\text { Oznaka }\end{array}$ & \multicolumn{1}{|c|}{$\begin{array}{c}\text { Form } \\
\text { Oblik }\end{array}$} & \multicolumn{1}{|c|}{$\begin{array}{c}\text { Wood species } \\
\text { Vrsta drva }\end{array}$} & \multicolumn{1}{c|}{ Mass loss, \% / Gubitak mase, \% } \\
\cline { 3 - 5 } & \multicolumn{1}{|c|}{ F. vaillantii } & G. trabeum \\
\hline A & Batten / letva & Scots pine / obični bor & $13.8(2.4)$ & $\mathbf{0 . 6}(0.1)$ \\
\hline B & Post / stup & Scots pine / obični bor & $20.0(4.1)$ & $9.8(0.4)$ \\
\hline C & Post / stup & Scots pine / obični bor & $20.2(3.3)$ & $\mathbf{3 . 0}(0.3)$ \\
\hline D & Post / stup & Norway spruce / visoka smreka & $17.6(2.7)$ & $39.4(3.1)$ \\
\hline E & Post / stup & Scots pine / obični bor & $10.8(1.8)$ & $\mathbf{0 . 9}(0.1)$ \\
\hline F & Batten / letva & Scots pine / obični bor & $17.7(1.5)$ & $\mathbf{1 . 3}(0.1)$ \\
\hline G & Batten / letva & Norway spruce / visoka smreka & $20.2(2.6)$ & $\mathbf{1 . 0}(0.0)$ \\
\hline H & Batten / letva & Scots pine / obični bor & $16.2(2.7)$ & $11.2(2.5)$ \\
\hline I & Batten / letva & Norway spruce / visoka smreka & $16.2(1.5)$ & $35.7(4.9)$ \\
\hline J & Post / stup & Norway spruce / visoka smreka & $17.9(4.1)$ & $5.3(0.3)$ \\
\hline & & & & $18.8(2.1)$ \\
\hline Control / Kontrolni uzorak & & Norway spruce / visoka smreka & $25.1(1.8)$ & $31.4(4.1)$ \\
\hline Control / Kontrolni uzorak & & Scots pine / obični bor & $33.2(3.8)$ \\
\hline
\end{tabular}


sible due to poor penetration (Samples A, D, E, G, I; Table 2). On the other hand, G. trabeum exhibited higher differentiation of the analysed wood species. Mass losses of five samples (A, C, E, F and G) did not exceed $3.0 \%$. This low mass loss is not always associated with high copper retention and good penetration. For example, low mass loss of sample A was associated with the presence of heartwood, which is much more durable than sapwood. The highest mass losses were determined with post D (39.4\%) and batten I (35.7\%), made of Norway spruce, which clearly indicates the susceptibility of spruce wood to brown rot decay.

\section{CONCLUSIONS}

4. ZAKLJUČAK

Samples of impregnated wood from hardware stores were analysed to determine the penetration, retention and fungicidal properties of the treated wood. The results of the analysis clearly indicated that none of the impregnated wood samples fully met the relevant European standards. It can be expected that these treated products will not meet the expectations of the end users due to premature failures. However, novel EN 350 procedure enables even classification of impregnated wood to durability classes. Unfortunately, there is no procedure available for that. Reduced durability of impregnated wood could be the result of poor penetration and/ or insufficient retention. However, existing experimental procedure does not allow to classify impregnated wood to durability classes as defined by EN 350 .

\section{Acknowledgemnt - Zahvala}

The authors acknowledge the support of the Slovenian Research Agency within the framework of project L4-5517, L4-7547, programme P4-0015 and the infrastructural centre (IC LES PST 0481-09: Part of the research was also supported by project Tigr4smart.

\section{REFERENCES}

\section{LITERATURA}

1. Brischke, C.; Meyer, L.; Alfredsen, G.; Humar, M.; Francis, L.; Flœte, P-O.; Larsson, P. B., 2013: Natural durability of timber exposed above ground: a survey. Drvna industrija, 64 (2): 113-129.

https://doi.org/doi:10.5552/drind.2013.1221

2. Connell, M., 2004: Issues facing preservative suppliers in a changing market for treated wood. Final Workshop COST Action E22. Environmental Optimisation of Wood Protection, Lisboa, Portugal, 22-23 March 2004, p. 8. http://citeseerx.ist.psu.edu/viewdoc/download?doi=10.1. $1.424 .3629 \&$ rep $=$ rep $1 \&$ type $=$ pdf.

3. Despot, R., 1998: Mechanism of infection of fir wood joinery; Part 2: Sequence and intensity of attack of microorganisms. Drvna industrija, 49: 135-144.

4. Humar, M.; Bučar, B.; Pohleven, F., 2006: Brown-rot decay of copper-impregnated wood. International biodeterioration \& biodegradation, 58 (1): 9-14. https://doi.org/doi:10.1016/j.ibiod.2006.03.003.
5. Humar, M.; Lesar, B., 2009: Influence of dipping time on uptake of preservative solution, adsorption, penetration and fixation of copper-ethanolamine based wood preservatives. European journal of wood and wood products, 67 (3): 265 270. https://doi.org/doi:10.1007/s00107-009-0317-1.

6. Humar, M.; Petrič, M.; Pohleven, F., 2001: Leaching of copper from wood treated with copper based wood preservatives. Drvna industrija, 52: 111-116.

7. Humar, M.; Thaler, N., 2017: Performance of copper treated utility poles and posts used in service for several years. International biodeterioration \& biodegradation, 116: 219226. https://doi.org/10.1016/j.ibiod.2016.11.004.

8. Lacić, R.; Hasan, M.; Trajković, J.; Šefc, B.; Šafran, B.; Despot, R., 2014: Biological durability of oil heat treated alder wood. Drvna industrija, 65 (2): 143-150.

https://doi.org/doi:10.5552/drind.2014.1256.

9. Preston, A., 2000: Wood preservation. Trends of today that will influence the industry tomorrow. Forest products journal, 50: 12-19.

10. Raspor, P.; Smole-Možina, S.; Podjavoršek, J.; Pohleven, F.; Gogala, N.; Nekrep, F. V.; Hacin, J., 1995: ZIM: zbirka industrijskih mikroorganizmov-Collection of industrial microorganisms. Katalog biokultur-Catalogue of cultures. Ljubljana, University of Ljubljana, Biotechnical Faculty, 98 p.

11. Wilkinson, J. G., 1979: Industrial timber preservation. London. Associated Business Press.

12. ${ }^{* * *}$ CEN, 2006: EN 113 - Wood preservatives - Test method for determining the protective effectiveness against wood-destroying basidiomycetes. Determination of toxic values. European Committee for Standardisation, Brussels, Belgium, 28.

13. *** CEN. 2007: EN 351-1 - Durability of wood and wood-based products - Preservative treated solid wood. Part 1: Classification of preservative penetration and retention. European Committee for Standardisation, Brussels, Belgium, 3, 22.

14. *** CEN. 2009 EN 599-1 - Durability of wood and wood-based products - Efficacity of preventive wood preservatives as determined by biological tests - Part 1 : Specification according to use class. European Committee for Standardisation, Brussels, Belgium, 41.

15. *** Nordic Wood Preservation Council, 2008: Wood preservatives approved by the Nordic Wood Preservation Council, Vol. List no. 78.

16. ${ }^{* * *}$ Nordic Wood Preservation Council, 2015: Wood preservatives approved by the Nordic Wood Preservation Council, Vol. List no. 92.

17. *** Regulation (EU) No 528/2012 of the European Parliament and of the Council of 22 May 2012 concerning the making available on the market and use of biocidal products. Official Journal L 167/1.

\section{Corresponding address:}

Prof. Dr. MIHA HUMAR, Ph.D.

University of Ljubljana, Biotechnical Faculty

Jamnikarjeva

SI-1000, Ljubljana, SLOVENIA

e-mail:miha.humar@bf.uni-lj.si 